\title{
From Print to Digital: A Revolution in the Order of Speeches
}

An Interview with Roger Chartier

De l'imprimé au numérique : une révolution de l'ordre des discours. Entretien

avec Roger Chartier

De lo impreso a lo digital : una revolución del orden del discurso. Entrevista con

Roger Chartier

\section{Cécile Rabot and Roger Chartier}

Translator. Katharine Throssell

\section{(2) OpenEdition}

\section{Journals}

Electronic version

URL: http://journals.openedition.org/bssg/479

DOI: $10.4000 /$ bssg. 479

ISSN: 2490-9424

Publisher

Presses universitaires de Vincennes

\section{Electronic reference}

Cécile Rabot and Roger Chartier, "From Print to Digital: A Revolution in the Order of Speeches", Biens Symboliques / Symbolic Goods [Online], 7 | 2020, Online since 20 November 2020, connection on 04 March 2021. URL: http://journals.openedition.org/bssg/479 ; DOl: https://doi.org/10.4000/bssg.479 
BIENS

SYMBOLIQUES

SYMBOLIC

GOODS
SYMBOLIQUES

Revue de sciences sociales sur les arts, la culture er les ides
A Social Science Journal on Arts. Culture and Ideas SYMBOLIC $\infty 2$ GOODS

is leurs racine tra

It des cassolettes d'encens et'finim

fums à la fois. Tout rit, chonte et

loucement ivre. Le printemps est

e; le soleil aide à faire patienter

des êtres qui n'en demandenit pas

gui, ayant l'azur du ciel, disenf

absorbés dans le prodige, jpuisant

la nature l'indifference du bien 2

ateurs du cosmos radieusement dist mi ne comne $n^{\circ} 7 / 2020$ as amion shasm

\section{Lire en numérique} Digital Readings 
De l'imprimé au numérique : une révolution de l'ordre des discours. Entretien avec Roger Chartier
From Print to Digital: A Revolution in the Order of Speeches.

An Interview with Roger Chartier

Cécile Rabot

traduction | translation

Katharine Throssel

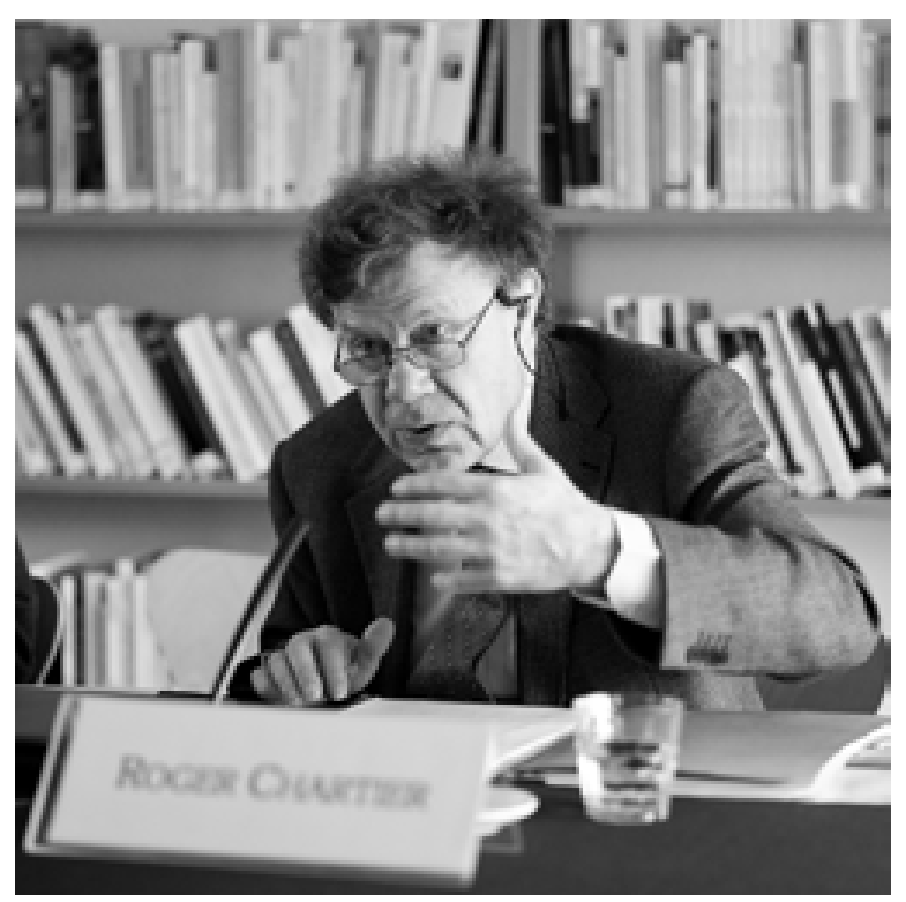

Roger Chartier au Centre français de recherche en sciences sociales / Roger Chartier at Centre français de recherche en sciences sociales (CEFRES), Prague, 2011. Source : Wikipédia, photo de Michael Wögerbauer / Wikipédia, picture by Michael Wögerbauer 
Cécile Rabot : - Vous avez porté une attention particulière, au fil de vos travaux, aux liens qui unissent les formes et les significations. Pouvez-vous préciser ces liens à travers quelques exemples ? Dans quelle mesure l'inscription des textes dans une matérialité détermine-t-elle la manière dont ils sont perçus et lus ?

Roger Chartier : - Le concept de « matérialité du texte » vise à surmonter l'opposition classique mais trompeuse entre, d'un côté, l'œuvre et, de l'autre, le livre ou l'objet imprimé. Cette distinction bien nette semble définir des tâches très différentes : celles des historien·ne-s de la littérature ou de la philosophie, vouéress à l'étude de la genèse et des significations des œuvres, et celle des historien.ne.s du livre ou de l'édition, attaché·e·s à la compréhension des modalités de publication et circulation des textes. Une telle distinction est pourtant mise en question par la " sociologie des textes " telle que l'a définie Donald Francis McKenzie (1991) et qui a pour point de départ l'étude des modalités de publication, de dissémination et d'appropriation des textes. Appuyée sur la tradition bibliographique, elle met l'accent sur la matérialité du texte et l'historicité du/de la lecteur.rice avec l'intention d'identifier les effets produits sur le statut, le classement et la perception des œuvres par les transformations de leur forme matérielle. C'est contre l'abstraction des discours, réduit à leur seule littéralité et littérarité, que l'étude de la matérialité du texte, entendue au sens qu'ont donné à cette expression Peter Stallybrass et Margreta de Grazia (1995), rappelle que la production, non pas seulement des livres, mais aussi celle des textes eux-mêmes, est un processus qui implique, au-delà du geste de l'écriture, différents moments, différentes techniques, différentes interventions. En effet, les transactions entre les œuvres et le monde social ne
Cécile Rabot: - Your work has emphasized the connections between forms and meanings. Could you give us a few examples of these connections? What is the extent to which the materiality of texts determines how they are perceived and read?

Roger Chartier: - The concept of the "materiality of the text" aims to move beyond the classic but misleading opposition between the work and the book or printed object. That very clear-cut distinction appears to define very different tasks: those of historians of literature or philosophy, pertaining to the study of the genesis and meanings of works, and those of historians of books and publishing, focused on elucidating the conditions of publication and circulation of texts. However, the above distinction has been challenged by the "sociology of texts" proposed by Donald Francis McKenzie (1986), which takes the study of the conditions of publication, dissemination, and appropriation of texts as a starting point. Drawing on the bibliographical tradition, it emphasizes the materiality of the text and the historicity of the reader in order to identify the effects of the transformation of the material form of works on their status, categorization, and perception.At odds with the abstraction of discourse reduced to its literality and literarity, the study of the materiality of the text, understood in the sense of Peter Stallybrass and Margreta de Grazia (1993), reminds us that the production, not only of books but also of texts themselves, is a process that encompasses different stages, techniques, and different interventions beyond the act of writing itself. Indeed, the transactions between the works and the social world do not only consist in the aesthetic and symbolic appropriation of ordinary objects, multiple languages, or ritual or everyday practices, which are all 
consistent pas uniquement dans l'appropriation esthétique et symbolique d'objets ordinaires, de langages multiples, de pratiques rituelles ou quotidiennes comme le veut (à juste titre) le New Historicism. Elles concernent plus fondamentalement les relations multiples, mobiles, instables, nouées entre une œuvre et ses différents textes. Ainsi, le processus de publication, quelle que soit sa modalité, ne sépare jamais la matérialité du texte de la textualité du livre.

Cette matérialité n'est pas seulement celle qui a retenu l'attention de la New Bibliography, soucieuse d'une description formalisée des objets imprimés afin de reconstituer le processus de leur impression et désireuse de reconnaître, grâce à l'identification des habitudes, des préférences ou du matériel typographique des compositeurs qui ont composé les différents cahiers ou feuilles du livre, les altérations qu'ils ont pu infliger à l'œuvre. La " matérialité du texte » renvoie à la « fonction expressive » des modalités d'inscription du texte dans le livre : le format, la mise en page, les choix graphiques et orthographiques, la ponctuation. Ces décisions, quel·le qu'en soit le/la responsable, " font le texte »-au moins pour les lecteur.rice-s de l'édition où elles se rencontrent. C'est en cela que, selon D. F. McKenzie, « forms affect meaning».

Nombreux sont les exemples de la mobilité des textes produite par la transformation de leurs formes matérielles d'inscription, d'édition et de circulation. Parmi ceux que j'ai étudiés, on peut mentionner les textes préalablement publiés comme des livres imprimés vendus par les libraires lorsqu'ils entrent dans les répertoires de la littérature de colportage (Bibliothèque bleue, chapbooks, pliegos sueltos), ou les pièces de théâtre rassemblées dans les CEuvres (le Folio de 1623 de Shakespeare, les CEuvres de Molière) après elements (rightly) emphasized by New Historicism. They are more fundamentally about the multiple, shifting, and instable relationships between a work and its different texts. The publication process, regardless of its form, never separates the materiality of the text from the textuality of the book.

This materiality is not only the materiality examined by New Bibliography, which called for a formalized description of printed objects to retrace their printing process and sought to identify habits reflecting the preferences or printing equipment of the typesetters who composed the pages of a book, and their alterations to the work. The "materiality of the text" also refers to the "expressive function" of the forms of inscription of the text in the book: format; layout; spelling and orthographic choices; and punctuation. Regardless of who takes them, such decisions "make the text"-at least for the readers of the edition in question. In that way, as D. F. McKenzie puts it, "forms affect meaning."

There are many examples of mobility of texts resulting from the transformation of their material forms of printing, publication, and circulation. Among those I have studied, I could for instance mention texts originally published as printed books to be sold by booksellers, which then entered the repertoire of peddler literature, sold by itinerant salesmen (for example, Bibliothèque bleue, chapbooks, "pliegos sueltos"), or theatrical plays printed together in collections of works (Shakespeare's folio of 1623 , Molière's CEuvres) after 
avoir circulé séparément en format in-quarto ou in-octavo. On pourrait ajouter l'exemple spectaculaire des romans du $\mathrm{XIX}{ }^{\mathrm{e}}$ siècle et leurs multiples formes de publication : feuilleton, publication par fascicules, anthologies, œuvre séparée, œuvres complètes, etc. Dans tous les cas, sont modifiés tout ensemble le statut de l'œuvre, les formes de sa publication et les conditions de sa réception.

Comme historien de l'écrit, vous vous intéressez en particulier aux moments de rupture de cette histoire. Quels sont-ils ? En quoi le numérique rompt-il avec l'ordre des discours qui préside à l'imprimé ?

Avant le numérique, les principales mutations de la culture écrite, toujours disjointes, furent l'apparition du codex, le livre constitué par des cahiers et feuillets reliés ensemble, substitué au rouleau des Grecs et des Romains entre le ${ }{ }^{e}$ et le IV siècle, l'invention de l'imprimerie typographique $\mathrm{au} \mathrm{XV}^{\mathrm{e}}$ siècle et les différentes révolutions de la lecture (la conquête de la lecture visuelle et silencieuse à partir du haut Moyen Âge, la lecture « extensive », rapide et critique, ajoutée à la lecture « intensive » au XVIII ${ }^{\mathrm{e}}$ siècle, ou l'entrée en lecture au $X I X^{e}$ siècle des enfants, dans et hors l'école, des milieux populaires et des femmes). La première originalité de la révolution numérique est la simultanéité de la transformation de ces trois registres : morphologique, technique et culturel.

La seconde est de mettre en question l'ordre des discours construit par les précédentes mutations. Nous sommes les héritiers de cet ordre. D'abord, pour la définition du livre, qui est pour nous, tout à la fois, un objet différent des autres objets circulating separately in quarto or octavo format. There is also the spectacular example of nineteenth century novels and their multiple forms of publication: as serials, fascicles, anthologies, separate works, complete works, etc. In each case, the status of the work, the forms of its publication and the conditions of its reception are all simultaneously altered.

As a historian of the written word, you have taken particular interest in the watersheds of that history. Could you list them for us? How does the digital shift break from the order of discourse that characterizes the printed word?

Before the advent of the digital era, the main, always disjointed revolutions in written culture were the rise of the codex - a book made up of leaves and quires bound together, which replaced Greek and Roman scrolls between the second and the fourth century - the invention of printing in the fifteenth century, and the successive revolutions in reading (the conquest of visual and silent reading from the Early Middle Ages; "extensive" reading - a fast, critical form of reading that supplemented "intensive" reading in the eighteenth century; and access to reading in and outside school for lower-class children and women in the nineteenth century). The major original aspect of the digital revolution is that it has brought transformations simultaneously in the morphological, technical, and cultural realms.

The second new aspect is that it calls into question the order of discourses constructed by previous revolutions. We are the inheritors of that order. This pertains first to the definition of the book, which to us is an object that differs from the other 
de la culture écrite et une œuvre intellectuelle ou esthétique dotée d'une identité et d'une cohérence assignées à son auteur.rice ou, pour citer Kant, un opus mechanicum et un discours adressé au public des lecteur.rice.s. Ensuite, et plus largement, pour une perception de la culture écrite fondée sur les distinctions immédiates, matérielles, entre des objets qui portent des genres textuels différents et qui impliquent des usages différents. C'est un tel ordre des discours que met en question la textualité électronique. En effet, c'est le même support, en l'occurrence l'écran de l'ordinateur, qui fait apparaître face au lecteur ou à la lectrice les différents types de textes qui, dans le monde de la culture manuscrite et a fortiori de la culture imprimée, étaient distribués entre des objets distincts. Tous les textes, quels qu'ils soient, sont produits ou reçus sur un même support et dans des formes très semblables, généralement décidées par le/la lecteur-rice lui/elle-même. Est ainsi créée une continuité textuelle qui ne différencie plus les genres à partir de leur inscription matérielle. De ce fait, c'est la perception des œuvres comme œuvres qui devient plus difficile. La lecture face à l'écran est généralement une lecture discontinue, qui cherche, à partir de mots clefs ou de rubriques thématiques, le fragment dont elle veut se saisir : un article dans un périodique électronique, un passage dans un livre, une information dans un site, sans que nécessairement doive être connue, dans son identité et sa cohérence propres, la totalité textuelle dont ce fragment est extrait. Le monde numérique ignore ainsi doublement le « livre »: comme objet matériel, remplacé par l'écran, et comme modalité du discours dont l'architecture narrative logique ou démonstrative, qui suppose la perception du lieu et du rôle de chaque fragment (chapitre, paragraphe, page) dans la totalité de l'œuvre, est appropriée par une lecture qui autonomise les unités textuelles dont elle s'empare. objects of written culture and an intellectual or aesthetic work whose author gives it an identity and consistency, or, to quote Kant, an opus mechanicum and a discourse addressed to an audience of readers. Second, more broadly speaking, we have inherited a perception of written culture that is based on the immediate, material distinctions between objects that support different textual genres and entail different uses. This order of discourse is challenged by digital textuality. Now, indeed, the same device-the computer screen-brings the reader a variety of texts that in the worlds of handwritten culture, and evidently of print culture, were distributed between distinct objects. All texts, regardless of their nature, are produced and received on the same object and in very similar forms, generally picked by readers themselves. This creates a textual continuum wherein genres are no longer distinguished on the basis of their material inscription. This in turn makes the perception of works as works more difficult. Screen reading is generally discontinuous, using keywords or thematic searches to locate fragments: an article in a digital journal, a passage in a book, a news item on a website, with no necessary awareness of the textual totality from which the fragment is extracted. The digital world thus doubly ignores the "book": as material object, replaced by the screen, and as a modality of discourse whose narrative, logical or demonstrative architecture, entailing the perception of the location and role of each fragment (chapter, paragraph, page) within the totality of the work, is appropriated by a form of reading that renders textual units autonomous. 
Le numérique est souvent caractérisé par la “ dématérialisation » qu'il introduirait. Qu'en pensezvous ? Peut-on à rebours considérer que lire en numérique et lire sur papier sont des gestes équivalents ?

D'une part, rien n'est plus matériel que le monde numérique, qui multiplie les objets dont les écrans sont les supports de la lecture et de l'écriture. L'incessante compétition entre les maîtres du marché pour proposer de nouveaux produits, la création des besoins qui conduiront à leur achat, les craintes quant à l'obsolescence des données numériques sont autant de preuves de cette matérialité.

D'autre part, rien n'est plus dangereux que l'idée immédiate et séduisante de l'équivalence : comme si lire un texte face à l'écran était équivalent à le lire dans ses éditions premières ou successives; comme si lire un journal ou une revue dans une forme ou une autre était une même lecture ; comme si acheter un livre en ligne ou en librairie était une même expérience. La lecture dans le monde de l'imprimé procède topographiquement et le/la lecteur.rice, comme le disent les métaphores, est un.e voyageur.se, un'e nomade, un braconnier pour Michel de Certeau. II/Elle construit le sens de chaque texte à partir de sa coexistence avec d'autres textes rassemblés dans un même objet. L'intertextualité, chère à la critique structuraliste, trouve là sa matérialité. La lecture numérique, elle, est thématique ; elle localise chaque texte dans la thématique à laquelle il appartient. Plusieurs conséquences découlent de cette différence fondamentale.

L'idée même de revue, par exemple, devient incertaine lorsque la consultation des articles n'est plus liée à la
The digital world is often described with an emphasis on the "dematerialization" it supposedly introduces. What are your thoughts on this? Might one conversely consider that reading digitally and on paper are similar activities?

On the one hand, there is nothing more material than the digital world, with its multiple computers whose screens serve as props for reading and writing. The ceaseless competition between market leaders to offer new products, to create need so that they will be bought, and fears regarding the obsolescence of digital data are all evidence of this materiality.

On the other hand, there is nothing more dangerous than the alluring idea that both activities are similar: as if reading a text on a screen were similar to reading in its original edition or one of its successive editions; as if reading a paper or journal in one form or the other were the same kind of reading; as if buying a book online or in a bookshop were the same experience. In the print world, reading works topographically, and the reader, as the metaphors put it, is a traveller, a nomad, or a poacher according to Michel de Certeau. He or she constructs the meaning of each text on the basis of its coexistence with other texts gathered in the same object. This is where the materiality of intertextuality, which is dear to structuralist criticism, lies. Digital reading, for its part, is thematic: each text is localized on the basis of the broader theme it addresses. This fundamental difference has several consequences.

The very concept of a journal, for instance, becomes uncertain when the consultation of articles is no longer derived from 
perception immédiate d'une logique éditoriale rendue visible par la composition de chaque numéro, mais est organisée à partir d'un ordre thématique de rubriques dans lequel chaque article a pour contexte les articles d'autres revues portant sur le même sujet. Et, si l'on admet que la forme affecte le sens, il est sûr que lire un livre $d u X v I^{e}$ ou $d u X I X^{e}$ siècle sur écran est, certes, s'approprier son contenu sémantique, mais dans l'ignorance de ce que furent les lectures des lecteur.rice-s du passé. De là, le rôle essentiel des bibliothèques, non seulement comme productrices de collections numérisées, mais aussi comme institutions où se maintient un lien possible entre présent et passé de la culture écrite.

La mobilité des relations entre le texte et ses supports, observable avec le numérique, n'existe-t-elle pas aussi pour l'imprimé, contrairement à une représentation fréquente de l'écrit comme forme définitivement figée?

Vous avez raison et la mobilité des textes dans leurs éditions imprimées est l'un des objets de mes recherches récentes. Cette mobilité a des raisons multiples : les transformations des formes de publication, comme on l'a dit ; les variantes textuelles, qu'elles soient produites par les révisions de l'auteur.rice, les décisions de l'éditeur-rice ou les pratiques des typographes ; les modalités d'attribution d'une même œuvre (anonymat, pseudonymes, nom d'auteur.rice) ; les migrations entre langues du fait des traductions, et, bien sûr, les lectures de leurs lecteur.rice-s. Ce constat oblige à réviser la standardisation des textes attribuée à l'imprimerie - en particulier par Elizabeth Eisenstein (1983). La reconnaître n'implique pas, en effet, d'ignorer tous les processus qui en limitent les effets, particulièrement à l'âge de l'ancien régime typographique entre la $\mathrm{mi}-\mathrm{xv}^{\mathrm{e}}$ siècle et les débuts the immediate perception of an editorial logic made visible by the composition of each issue, but is organized on the basis of a thematic classification in which each article is placed in the context of articles from other journals on the same subject. If we allow that form affects meaning, it is clear that reading a sixteenth- or nineteenth-century book on a screen is admittedly appropriating its semantic content, but doing so without being aware of the reading experiences of past readers. This is where libraries play a key role, not only as producers of digitized collections, but also as institutions that maintain the possibility of a link between the present and the past of written culture.

Doesn't the mobility of the relationships between the text and its formats observed in the digital world also exist with print, even though the written word is frequently represented as a definitively fixed form?

You are right, and the mobility of texts in their printed editions have featured in my recent research. There are multiple reasons for this mobility: the transformations of forms of publication, as previously noted; the textual variations, which may be produced by the author's revisions, the publisher's decisions or the typographers' practices; the modalities of the attribution of a same work (anonymous, under a pseudonym or the author's name); the migrations between languages due to translations; and, of course, the readings of their readers. All the above calls for nuancing the idea that print led to a standardization of texts-put forward especially by Elizabeth Eisenstein (1983). Recognizing this doesn't mean we should ignore all the processes limiting its effects, particularly in the age of the old typographical regime, between the mid-fifteenth and the early nineteenth centuries: corrections were made 
du XIX siècle : les corrections sous presse faites en cours de tirage et qui, du fait de la pluralité des associations possibles entre feuilles corrigées et non corrigées dans les exemplaires d'une même édition, multiplient les états du " même » texte, les marginalia manuscrites, qui singularisent l'exemplaire approprié par un·e lecteur.rice particulier·ère, ou le rassemblement dans un même volume, et par la volonté de l'éditeur.rice ou du/de la lecteur.rice, de divers textes, tant imprimés que manuscrits, réunis de manière unique dans une même reliure. Le texte imprimé est donc ouvert à la mobilité, à la flexibilité, à la variation, ne serait-ce que parce qu'en un temps où les tirages demeurent limités (entre mille et mille sept cent cinquante exemplaires), le succès, donc la reproduction d'une œuvre, suppose de multiples rééditions, jamais tout à fait identiques les unes avec les autres. La capacité de l'imprimerie à reproduire un texte identique dans chacun des exemplaires d'une même édition ou entre différentes éditions n'implique pas qu'il en soit réellement ainsi. À l'inverse, on peut le noter, la transmission manuscrite ne signifie pas nécessairement l'altération des textes, en particulier lorsque, comme dans le cas des écrits sacrés, leur lettre est fixée et qu'un strict contrôle est exercé sur leur copie.

II me semble que cette mobilité n'est pas comparable à celle permise ou promise par le monde numérique. L'obsession, peut-être excessive, pour la numérisation de livres déjà là, ne doit pas masquer un autre aspect de la « grande conversion numérique », pour reprendre l'expression de Milad Doueihi (2008), à savoir, la capacité de la nouvelle technique à porter des formes d'écriture et de publication originales, libérées des contraintes imposées, à la fois, par la morphologie du codex et le régime juridique du copyright. Cette écriture numérique peut être polyphonique et palimpseste, ouverte et during the printing process, and which, due to the multiplicity of possible associations of corrected and uncorrected sheets in copies of the same edition, resulted in multiple states of the "same" texts; handwritten marginalia singularized a copy as appropriated by a particular reader; and sometimes out of the publisher's or the reader's will, various texts, both printed and handwritten, were collected in unique bound volumes. The printed text is thus open to mobility, to flexibility, to variation, if only because at a time when print runs were limited (between 1,000 and 1,750 copies), the success, and by extension the reproduction of a work entailed multiple reprints, which were never entirely identical. The ability of the print press to reproduce an identical text in each copy of the same edition or in different editions of the same text does not mean that this was done. Conversely, it is worth noting that handwritten transmission did not necessarily result in the alteration of texts, especially when, as in the case of sacred texts, layout was standardized and copying was subject to strict control.

I don't think this mobility can be compared to what the digital world allows or promises. The perhaps excessive obsession with the digitalization of already existing books should not conceal another aspect of the "great digital conversion," as Milad Doueihi (2011) calls it, which is the ability of the new technology to bring about original forms of writing and publication, freed from the constraints both of the codex's morphology and of legal regime of copyright. This digital writing can be polyphonic and palimpsestic, open and malleable, infinite and shifting. This is why it disrupts the categories 
malléable, infinie et mouvante. C'est pourquoi elle bouscule les catégories qui, depuis le XVIII siècle, sont le fondement de la propriété littéraire : l'originalité des œuvres qui demeurent toujours identiques à elles-mêmes en dépit de leur mobilité, la singularité d'une autorité « auctoriale » à laquelle l'œuvre est assignée, la publication des textes dans des objets où le/la lecteur.rice peut intervenir, mais seulement dans les espaces laissés en blanc par la composition typographique. Une preuve de la spécificité de la mobilité numérique, qui peut effacer toutes ces catégories, est donnée, a contrario, par les efforts de l'édition numérique que s'efforce d'introduire, dans une technique apte à les supprimer, les notions propres à la culture imprimée : auteur·rice, œuvre, propriété intellectuelle.

\section{Vous avez montré comment la lecture est devenue peu à peu une pratique privée. Le numérique change-t-il quelque chose à cet égard ?}

La « privatisation » de la lecture est, en effet, une des caractéristiques essentielles de son histoire, qui conduit au cantonnement institutionnel de la lecture à haute voix, faite pour un public d'auditeur.rice·s, dans les sociétés contemporaines. Alors qu'elle était présente dans toutes les formes de sociabilité (familiale, amicale, lettrée, militante) jusqu'au XIX ${ }^{e}$ siècle, la lecture à haute voix s'est limitée à l'école et à l'université, à l'église et au tribunal, ou bien à la relation entre parents et enfants. II est vrai que dans le présent, elle a repris vie, dans différentes formes : les lectures de leurs œuvres par des auteur.rice-s invité e.s par les librairies ou les bibliothèques, les audio-livres qui ont débordé leur première destination à l'usage des malvoyant $\cdot e \cdot s$, ou les performances théâtrales d'acteur.rice·s qui disent les œuvres. Quel rôle that have been the building blocks of literary property since the eighteenth century: the originality of works, which always remain identical to themselves despite their different embodiments, the singularity of an "auctorial" authority to which the work is attributed, the publication of texts in objects in which the reader can intervene, but only in spaces left blank by the typesetting. Evidence of the specificity of digital mobility, which can erase all these categories, is conversely given by the efforts of the digital publishing trade to introduce the key concepts of printed culture (author, work, intellectual property) in a technology that is open to their disappearance.

Your work has shown how reading gradually became a private practice. Does the digital world change anything in that respect?

The "privatization" of reading has indeed been one of the key characteristics of its history, leading to the institutional limitation of oral reading for an audience of listeners in contemporary societies. Previously present in all forms of sociability (familial, friendly, lettered, activist) until the nineteenth century, oral reading was limited to schools and universities, churches and courts, and to the parent/child relationship. Admittedly, these days, it has been revived in various forms: readings of works by authors invited to bookshops or libraries; audiobooks, which initially targeted the visually impaired but now appeal to a broader audience; as well as theatrical performances by actors who recite works. 


\section{faut-il attribuer au numérique dans ces mutations contemporaines?}

La lecture numérique, qui reste généralement celle d'un·e lecteur-rice solitaire et silencieux·se, peut conduire, grâce aux réseaux sociaux, au partage des conseils, des critiques, des interprétations ou des annotations. Des communautés de lecture sont ainsi constituées qui associent le privé de l'acte de lire avec la mise en commun des réactions de lecture. Le numérique donne ainsi réalité à la définition kantienne de l'espace public et de l'usage critique de leur raison par des personnes privées adressant au public des lecteur-rice-s leurs observations et réflexions. Reste, toutefois, une différence entre cette mise en commun et les formes anciennes du partage de l'écrit : dans le monde numérique, l'échange ne suppose plus la présence dans un même lieu. Cette présence était celle de l'agora des cités grecques, des sociabilités intellectuelles et politiques du temps des Lumières, ou de la manifestation de la volonté générale telle que la pensait JeanJacques Rousseau. C'est pourquoi il est sans doute heureux que, dans nos sociétés, certaines institutions, bibliothèques ou librairies, retrouvent le lien ancien (et longtemps dénoué) entre la parole et l'écrit, les voix des textes et celles des lecteur.rice.s.

Que change le numérique à la textualité ? Accroît-il les possibilités d'appropriation ? Va-t-il jusqu'à modifier l'ordre des propriétés et la fonction auteur et doit-il nous conduire à repenser le droit d'auteur?

Le numérique lance effectivement un grand défi à l'ordre des propriétés, si l'on entend le terme «propriété » aussi bien
What role should be attributed to the digital world in these contemporary mutations?

Digital reading-which generally remains the practice of solitary, silent readers-may, thanks to social media, lead to the sharing of recommendations, criticism, interpretation, and annotation. Readers' communities combine the private act of reading with the pooling of reactions. The digital world thus realizes the Kantian definition of public space and the critical use of their reason by private persons who submit their observations and thoughts to the reading audience. There is, however, one remaining difference between this pooling and the old forms in which the written word was shared: in the digital world, exchanging no longer entails being present in the same place. This presence characterized the agora in Greek cities, the intellectual and political forms of sociability of the Enlightenment era, and the manifestation of general will conceived by Jean-Jacques Rousseau. This is why it is probably a good thing that in our societies, some institutions, libraries, and bookshops have re-established the old (and long-broken) connection between speech and the written word, and between the voices of the texts and those of the readers.

How does the digital world affect textuality? Does it increase possibilities of appropriation? Does it go so far as to change the order of properties and the author function, and should it lead us to rethink the idea of copyright?

The digital world indeed presents a great challenge to the order of properties, if we consider "properties" both in a 
dans un sens juridique, celui qui fonde la propriété littéraire et le copyright, que dans un sens textuel, qui désigne les caractéristiques propres de chaque genre discursif. Parce qu'il est possiblement malléable et ouvert, le texte numérique ne peut pas être l'objet d'une propriété, sauf s'il est immobilisé par une édition qui en interdit la transmission, la copie ou l'impression - ce qui est le cas avec les milliers de revues scientifiques à très hauts prix de souscription publiées par Springer, Elsevier ou Wiley. Les différences sont donc grandes entre les livres numérisés, publiés en respectant droits d'auteur et copyright, et les livres numériques, composés selon les logiques et ressources propres à la publication électronique et qui peuvent donner réalité au rêve de Foucault à propos de la disparition de la « fonction auteur » (Foucault 1969 : 73104) et à la possibilité de créations esthétiques qui associent textes, images et sons en même temps qu'elles supposent les décisions et interventions de leurs lecteur.rice-s. Dans le cas des livres pour enfants, l'exploitation de ces possibilités substitue souvent le site au livre, l'œuvre ouverte au texte clos et la gratuité de l'accès au marché éditorial.

\section{Que change en particulier le numérique à la pratique de l'historien·ne et aux conditions du travail intellectuel ?}

Les mutations se situent à chaque moment ou modalité du travail historien. L'accès aux sources, tout d'abord, avec la possibilité d'une consultation des documents numérisés (archives, livres anciens, bibliographie récente). Les opérations de recherche, ensuite, avec la constitution de bases de données bibliographiques ou statistiques, les traitements quantitatifs impossibles auparavant, ou, comme on le voit avec les manuscrits médiévaux, la possibilité legal sense, the basis of literary property and copyright, and in a textual sense, meaning the distinct characteristics of each discursive genre. Since it can be malleable and open, the digital text cannot be the object of property, unless it is restricted by an edition that forbids circulation, copying, or printing - which is the case for the thousands of highly priced subscription journals published by Springer, Elsevier, or Wiley. There are considerable differences between digitized books, which are published in compliance with authors' rights and copyright, and digital books, which follow the logics and rely on the resources of digital publishing, and may make Foucault's dream about the disappearance of the "author function" (Foucault 1979) come true as well as enable aesthetic creations that combine text, image, and sound and allow for the decisions and interventions of their readers. In the case of children's books, harnessing these opportunities often means replacing books with websites, closed-ended texts with open-ended works, and giving free access to the publishing market.

\section{What does the digital world change specifically in the historian's practice and in the conditions of intellectual work?}

There are changes at every step and in every form of the historian's work. First, access to sources has changed, with the possibility of consulting digitized documents (archives, old books, recent bibliography). Research operations are also different, with the constitution of bibliographical or statistical databases, the previously impossible quantitative treatments that can now be performed, or, as we can see with medieval manuscripts, the possibility to see what cannot be seen by 
de voir ce qui ne l'est pas par la lecture ou la consultation du document original. L'écriture de l'histoire, enfin, avec une manière inédite d'organiser une argumentation et les possibilités qu'a le/la lecteur.rice pour l'accepter ou la refuser. Du côté de l'auteur.rice, la textualité électronique permet de développer des démonstrations selon une logique qui n'est plus nécessairement linéaire ou déductive, comme l'est celle qu'impose l'inscription d'un texte sur une page. Elle permet une articulation ouverte, éclatée, relationnelle, du raisonnement, rendue possible par la multiplication des liens hypertextuels. Du côté du/de la lecteur.rice, la validation ou la récusation d'un argument peut désormais s'appuyer sur la consultation des textes (mais aussi des images fixes ou mobiles, des paroles enregistrées ou des compositions musicales) qui sont l'objet même de l'étude, à condition, évidemment, qu'ils soient accessibles en une forme numérisée. Si tel est le cas, le/la lecteur.rice n'est plus seulement obligé·e d'accorder sa confiance à l'auteur.rice ; il/elle peut à son tour, s'il/elle en a le goût ou le loisir, refaire tout ou partie du parcours de la recherche. II y a là une mutation épistémologique fondamentale, qui transforme profondément les techniques de la preuve et les modalités de construction et de validation des discours de savoir.

Dans le monde de l'imprimé, un livre d'histoire suppose un pacte de confiance entre l'historien 'ne et son/sa lecteur-rice. Les notes renvoient à des documents que le/la lecteur-rice, généralement, ne pourra pas lire. Les références bibliographiques mentionnent des livres que le/la lecteur-rice, le plus souvent, ne pourrait trouver que dans des bibliothèques spécialisées. Les citations sont des fragments découpés par la seule volonté de l'historien.ne, sans possibilité pour son lectorat de connaître la totalité des textes qui contiennent reading or consulting the original document. Lastly, the writing of history itself has changed, with unprecedented ways of presenting an argument and opportunities for readers to accept or refuse them. For authors, digital textuality allows for the development of demonstrations according to rationales that are no longer necessarily linear or deductive, unlike those required by the inscription of text on a page. A reasoning can be articulated in an open, fragmented, relational manner, thanks to the proliferation of hypertext links. For readers, the validation or recusal of an argument can now be informed by the consultation of texts (as well as the still or moving images, recorded words or musical compositions) that are the very object of study, provided of course they are accessible in digitized form. If that is the case, not only are readers no longer forced to trust the author; they can, in turn, if they have the inclination or time to do so, retrace all or part of the research steps. This is a fundamental epistemological change, which has been deeply transformative in terms of the techniques used to produce evidence and the modalities of construction and validation of scholarly discourse.

In the world of print, a history book entails a pact of trust between historian and reader. Notes reference documents that the reader will generally be unable to consult. Bibliographical references mention books that they would generally only be able to find in specialized libraries. Citations are fragments and their selection is the result of the writer's will alone, while the reader is unable to be familiar with the totality of the text(s) containing these passages. These three classic forms of production of evidence (note, reference, and citation) are 
ces passages. Ces trois dispositifs classiques de la preuve (la note, la référence et la citation) se trouvent profondément modifiés dans le monde de la textualité numérique à partir du moment où le/la lecteur.rice est mis·e en position de pouvoir lire à son tour le livre lu par I'historien-ne et consulter lui/ elle-même les documents analysés. Les premiers usages de ces nouvelles modalités de production, d'organisation et d'accréditation des discours de savoir montrent l'importance de la transformation des opérations cognitives impliquées par le recours au texte électronique.

\section{L'édition de revues scientifiques vous paraît-elle exemplaire de ce qui se joue dans le numérique, en termes de diffusion, de droit d'auteur et de lecture?}

Tout à fait. La tension entre la communication gratuite des idées et l'édition qui fixe et ferme les textes est un enjeu majeur des conflits entre les communautés scientifiques et les éditeurs. Ces dernières années, une controverse très forte a opposé les revues scientifiques, qui ont multiplié les éditions électroniques protégées par des « securities» interdisant la copie ou l'impression des articles de façon à maintenir un marché captif pour des revues dont les abonnements peuvent coûter jusqu'à quinze ou vingt mille dollars, et les chercheur.se·s, qui réclament le libre accès aux avancées du savoir. Deux logiques s'affrontent ici : la logique intellectuelle d'une communication gratuite, qui renvoie à l'idéal des Lumières du partage de la connaissance, et la logique économique, elle aussi héritée des Lumières, de la publication fondée sur les notions de droit d'auteur et de profit commercial. En 2001, quatorze mille chercheur.se.s, principalement dans le domaine de la biologie, signèrent une pétition qui exigeait l'accès gratuit et immédiat aux articles deeply altered in the world of digital textuality, insofar as readers are now able to read the book read by the historian and consult the analysed documents. The first uses of these new forms of production, organization, and accreditation of scholarly discourse show the extent of the transformation of the cognitive operations implied by the recourse to digital texts.

Do you see the field of scientific journal publishing as a paradigmatic example of what is at stake in the digital realm, in terms of dissemination, copyright, and reading?

Very much so. The tension between the free communication of ideas and publications that frame and limit access to texts has been a critical focal point in the conflicts between scientific communities and publishers. In recent years, there has been considerable controversy between scientific journals, which increasingly have recourse to securities-protected digital editions that make copying or printing papers impossible so as to retain a captive market for journals with subscriptions that may cost up to 15 or 20,000 dollars, and researchers, who are demanding free access to advances in knowledge. There are two opposite approaches in play here: the intellectual logic of free communication, harking back to the Enlightenment ideal of the sharing of knowledge, and the economic logic, also inherited from the Enlightenment, of publication based on the concepts of copyright and commercial profit. In 2001, 14,000 researchers, mainly in the field of biology, signed a petition that demanded immediate and free access to papers published in scientific journals. Today, the Public Library of 
des revues scientifiques. Aujourd'hui, la Public Library of Science publie sept revues en libre accès en génétique, biologie et médecine. En réponse à ces initiatives, certaines revues numériques (par exemple Molecular Biology of the Cell ou Science) ont finalement accepté que leurs articles soient librement consultables après quelques mois ou une année d'accès payant.

La lecture des revues scientifiques numériques est un exemple paradigmatique de la logique qui gouverne le monde numérique, dans lequel le contexte n'est plus celui donné par l'objet imprimé mais celui organisé par un ordre thématique. Ce qui est en jeu est la notion même de revue puisque disparaît la forme matérielle qui faisait percevoir et comprendre la logique (scientifique, intellectuelle, esthétique, politique, etc.) qui réunissait dans un même numéro des articles dont les genres ou les objets pouvaient être fort divers.

Quels défis lenumériquecrée-t-il ? Entermeslinguistiques, bibliothéconomiques, pédagogiques? Comment le numérique modifie-t-il le rôle des professionnels et des instances de légitimation des savoirs et des écrits ?

Les défis lancés par le monde numérique sont bien connus. Linguistiquement, il est celui de la domination d'une langue « universelle », l'anglais, du fait du contrôle par les puissantes entreprises américaines du marché des bases de données, des moteurs de recherche et de l'information. Pour les bibliothèques, le défi consiste à associer leur rôle traditionnel, plus nécessaire que jamais, de conservation et communication du patrimoine écrit avec leur entrée dans le monde numérique et la constitution ou l'acquisition de collections électroniques. Une telle association ne doit jamais
Science publishes seven open access journals in the fields of genetics, biology, and medicine. In response to these initiatives, some digital journals (including Molecular Biology of the Cell and Science) have eventually agreed to release their papers from the paywall after a few months or a year.

The reading of digital scientific papers is a paradigmatic example of the prevailing logic in the digital world, in which context is no longer given by the printed object, but by a thematic order. The very concept of the journal is at stake here, with the disappearance of the material form that conveyed the logics (scientific, intellectual, aesthetic, political, etc.) based on which a series of sometimes quite diverse papers (in terms of genre and topic) were collected in the same issue.

What challenges does the digital world raise, in linguistic and educational terms, and for libraries? How does it change the role of professionals and of the bodies that have traditionally legitimized knowledge and writing?

At this point, these challenges have been clearly identified. Linguistically, there is the domination of a "universal" language, English, as a result of the prevalence of powerful US corporations in the database, search engine, and information markets. For libraries, the challenges consist in combining their traditional role, which is more necessary than ever, of preserving and passing our written heritage with their introduction into the digital world and the building or acquisition of digital collections. This should never be done if both are considered to be equivalent, and it should always be 
se situer dans l'ordre de l'équivalence et la lecture numérique (qui, au demeurant, peut très bien se passer de la bibliothèque) ne doit pas faire oublier la lecture des documents originaux, tant pour les chercheur.se-s, puisque la forme matérielle affecte le sens intellectuel ou esthétique, que pour tous les lecteurs et lectrices soucieux ses de l'intelligibilité du passé. Pour l'enseignement, le défi est parallèle : d'une part, utiliser les nouvelles techniques comme aide à l'apprentissage, et, d'autre part, maintenir l'apprentissage de l'écriture manuscrite (ce que ne font plus plusieurs États des États-Unis) et la connaissance du monde des imprimés.

Mais, pour les bibliothèques et les écoles, une autre exigence est née face au monde numérique, qui est la plus puissante machine jamais construite de diffusion d'erreurs, falsifications, fausses nouvelles et faux savoirs. La culture numérique n'est pas seulement celle des livres numérisés ou numériques, loin s'en faut ; elle est massivement celle des plateformes et sites qui multiplient les falsifications, les théories les plus absurdes et les manipulations politiques. C'est là une autre grande différence avec le monde de l'imprimé dans lequel un ordre de la « vérité » des discours est établi à partir de critères immédiatement visibles : le genre des textes, l'identité des éditeurs, les choix des libraires et des bibliothèques. II n'en va plus de même dans le monde du numérique où tous les textes ont le même support et les mêmes formes, une même circulation et un même mode de lecture (comme l'ont montré plusieurs enquêtes, l'une des caractéristiques de la lecture des digital natives est justement la faible préoccupation pour le contrôle de la véracité des discours lus sur les écrans). De là, la prise de conscience d'une nouvelle tâche pour les bibliothécaires : enseigner aux lecteur.rice-s les critères et dispositifs, moins évidents que dans la culture imprimée, qui emphasized that digital reading (which in effect can very well do without libraries) cannot replace the reading of original documents-both for researchers, since material forms affect intellectual or aesthetic meaning, and for all readers eager to understand the past. For teaching, there is a twofold challenge: on the one hand, technology-enhanced learning should be used, but on the other, handwriting should still be taught (which is no longer the case in several US states) and knowledge of the print world should be passed on.

However, for libraries and schools, the digital world poses an additional challenge as it is the most powerful machine for spreading errors, falsehoods, fake news and fake knowledge ever devised. The digital world is far from limited to digital and digitized books; it includes a massive wealth of platforms and websites that circulate falsified knowledge, absurd theories, and political manipulations. This is another notable difference from the print world, in which the order of discursive "truths" is established on the basis of immediately visible criteria: the text genre, the publisher's identity, the choices of booksellers and librarians. This no longer applies in the digital world, where all texts are presented on the same device and in the same form, with the same circulation and the same mode of reading (several studies have shown that one of the defining features of reading for digital natives is precisely a low level of concern for the truthfulness of discourse read on screens). This puts librarians in the position of taking on the new task of teaching readers about the criteria and means to sort and hierarchize digital discourse, which are not as evident as in print. This should also be a duty for schools, if we want the digital world to serve as an instrument for building a rational, 
permettent de trier et hiérarchiser les discours numériques. Cette tâche devrait être aussi celle de l'école si l'on veut que le monde numérique soit un instrument de la construction d'un espace public lucide et critique, et non une puissante machine au service des pires propagandes.

Parleriez-vous, au total, de révolution induite par le numérique et/ou, au moins, d'une reconfiguration de la place de l'imprimé ?

Révolution me paraît le terme juste, même si, dans notre présent, la perception de cette révolution est atténuée par la résistance de la culture de l'imprimé (partout dans le monde, les livres imprimés dominent le marché du livre : plus de $90 \%$ en France ou au Brésil, 80 \% aux États-Unis, avec une diminution de la part du livre numérique ces dernières années). Cette situation perdurera-t-elle comme le pensent Umberto Eco et Jean-Claude Carrière (2009) (et comme nous voulons le penser avec eux) ? Deux raisons, pourtant, introduisent le doute. D'une part, toutes les institutions de la culture imprimée connaissent crise ou difficultés : les librairies ferment, impuissantes devant la concurrence du e-commerce, certains journaux, et non des moindres, abandonnent leur édition imprimée, et les bibliothèques succombent parfois à la tentation numérique en reléguant hors de leurs murs leurs collections imprimées. Autant de périls pour le livre imprimé. Il en est un autre.

Les pratiques des plus jeunes lecteur.rice.s et «écrivain·e.s », ces wreaders du néologisme anglais, sont immédiatement des pratiques de la fragmentation des textes, de la discontinuité des lectures, de l'accélération des attentes et des communications. Ces pratiques, quotidiennes et critical public space and not as a powerful machine at the service of the worst propaganda.

\section{Would you say the digital world has induced a revolution, and/or, at least, a reconfiguration of the place of print?}

I think revolution is the right term, even if the current perception of this revolution is mitigated by the resistance of print culture (printed books dominate the book market all over the world: over $90 \%$ of sales in France and Brazil, and $80 \%$ in the US, with proportions of digital book purchases decreasing in the past few years). Will this state of affairs last, as Umberto Eco and Jean-Claude Carrière (2012) seem to think (and as l'd like to think too)? Two reasons suggest that it might not, however. First, all the institutions of print culture are struggling or in crisis: bookshops are closing; powerless against e-commerce, some newspapers, including prominent titles, have discontinued their print editions; and libraries sometimes succumb to the digital temptation by moving out their print collections. This poses a danger for printed books.

Second, the practices of younger readers and writers, "wreaders" as they have been called, involve the fragmentation of text, the discontinuity of reading, and the acceleration of expectations and communications. These everyday practices, occurring on multiple devices such as smartphones, 
multipliées sur les mobiles et les «smartphones », ne peuvent pas ne pas avoir d'effets sur les relations avec la culture écrite dans laquelle le livre tenait et tient encore une place centrale. Pourra-t-il la garder ? Comme je l'ai dit, rien ne l'assure, même si sa mort ne surviendra pas dans le temps court qu'annonçaient les dirigeants de Microsoft au Congrès des éditeurs (effrayés puis sceptiques) réuni à Buenos Aires en 2000

Cécile Rabot

Université Paris Nanterre - Centre européen de sociologie et de science politique-Centre de sociologie européenne (CESSP-CSE)

\section{Références bibliographiques}

CARRIÈre Jean-Claude \& Eco Umberto (2009). N'espérez pas vous débarrasser des livres. Entretiens menés par Jean-Philippe de Tonnac. Paris, Grasset.

DOUEIHI Milad (2008). La Grande Conversion numérique. Traduit de l'anglais par Paul Chemla. Paris, Seuil.

EISENSTEIN Elizabeth L. (1983). The Printing Revolution in Early Modern Europe by Elizabeth L. Eisenstein. Cambridge, Cambridge University Press.

Foucault Michel (1969). «Qu'est-ce qu'un auteur ?». Bulletin de la Société française de philosophie, 63(3) : 73-104.

GraZiA Margreta (DE) \& STALLYBRASs Peter (1995) [1993]. « La matérialité du texte shakespearien ». Traduit de l'anglais par Delphine Lemonnier et François Laroque. Genesis (Manuscrits-Recherche-Invention), 7 : 9-27.

McKENZIE Donald Francis (1991) [1986]. La Bibliographie et la sociologie des textes. Traduit de l'anglais par Marc Amfreville. Paris, Cercle de la librairie. necessarily affects relationships to written culture, in which books have played and still play a central role. Will books resist this? As I have said, this is not guaranteed by any means, although they will not disappear in the short term, as Microsoft executives claimed before (scared, then sceptical) participants at the 2000 Buenos Aires International Publishers Congress.

Cécile Rabot Université Paris Nanterre - Centre européen de sociologie et de science politique-Centre de sociologie européenne (CESSP-CSE)

\section{References}

CARRIĖre Jean-Claude \& Eco Umberto (2012)[2009]. This is Not the End of the Book. A Conversation Curated by Jean-Philippe de Tonnac. Translated from French by Polly McLean. Evanston, Northwestern University Press.

DouElHI Milad (2011). Digital Cultures. Cambridge, Harvard University Press.

EISENSTEIN Elizabeth L. (1983). The Printing Revolution in Early Modern Europe by Elizabeth L. Eisenstein. Cambridge, Cambridge University Press.

Foucault Michel 1979. "What Is an Author ?" In HaRaRI Josué V. (ed.). Textual Strategies : Perspectives in Post-Structuralist Criticism. Translated by Josué V. Harar. Ithaca, Cornell University Press : 141-160. [Accessed on 15 June 2020.]

GraziA Margreta (DE) \& Stallybrass Peter (1993). "The Materiality of the Shakespearian Text." Shakespeare Quarterly, 44(3) : 255-283.

MCKENZIE Donald Francis (1986). Bibliography and the Sociology of Texts. London, British Library. 